Original Research Paper

\title{
Pemberdayaan Masyarakat selama Pandemik Covid-19 di RT 001/008 Bulakrejo Kecamatan Sukoharjo Kabupaten Sukoharjo
}

\author{
Ratna Dewi Eskundari $^{1 *}$, Agus Purwanto ${ }^{1}$, Suwarto ${ }^{1}$ \\ ${ }^{1}$ Program Studi Pendidikan Biologi, Fakultas Keguruan dan Ilmu Pendidikan, Universitas Veteran Bangun \\ Nusantara, Sukoharjo, Indonesia
}

https://doi.org/10.29303/jpmpi.v3i2.1358

Sitasi: Eskundari, R. D., Purwanto, A \& Suwarto. (2022). Pemberdayaan Masyarakat selama Pandemik Covid-19 di RT 001/008 Bulakrejo Kecamatan Sukoharjo Kabupaten Sukoharjo. Jurnal Pengabdian Magister Pendidikan IPA, 5(1)

\author{
Article history \\ Received: 31 Desember 2021 \\ Revised: 01 Februari 2022 \\ Accepted: 05 Februari 2022 \\ *Corresponding Author: Ratna \\ Dewi Eskundari, Program Studi \\ Pendidikan Biologi, Fakultas \\ Keguruan dan Ilmu Pendidikan, \\ Universitas Veteran Bangun \\ Nusantara, Sukoharjo, \\ Indonesia. \\ Email: \\ ratnaeskundari87@gmail.com
}

\begin{abstract}
The Covid-19 pandemic has a negative impact, especially in the economic sector throughout the world, including in Indonesia, and in this activity is the RT community. 001/008 Bulakrejo Sukoharjo Regency. The purpose of this community service is to empower the community in RT 001/008, Bulakrejo Village, Sukoharjo District, Sukoharjo Regency during the Covid-19 pandemic. The method used in this service was the lecture and mentoring method. The material presented was the manufacture of ecoenzyme with raw materials in the form of fruit and vegetable waste.

Initial observations of partners' conditions showed that the community in RT 001/008, Bulakrejo Village, Sukoharjo District, Sukoharjo Regency has not been able to make environmentally friendly ecoenzyme that can be economically useful, for example, can be used as plant biological fertilizer or fish feed. For this reason, further assistance was needed so that in making this ecoenzyme more acceptable to the community so that it can make more production and a wider market. The results of community service activities carried out three times showed that partner communities can practice making and harvesting ecoenzymes. Thus, it can be said that this activity succeeded in meeting its target.
\end{abstract}

Keywords: Covid-19; Ecoenzymes; Empowerment

Pandemi ini sangat berdampak pada semua sektor kehidupan masyarakat dunia, khususnya sektor ekonomi. Data yang diperoleh dari web lipi.go.id menyatakan bahwa perekonomian pada kuartal ke-II tahun 2020 menurun hingga -5,32\% dan sektor yang paling terdampak adalah sektor rumah tangga. Hal ini terlihat melambatnya konsumsi rumah tangga yang diyakini sebagai penopang utama perekonomian sehingga berakibat pada turunnya kinerja industri dan usaha mikro, kecil, dan menengah (UMKM). Selanjutnya banyaknya pemutusan hubungan kerja (PHK), pemangkasan gaji, serta penurunan keuntungan usaha memperparah kondisi perekonomian terutama pada sektor rumah tangga. Hasil survei yang dilakukan LIPI pada tahun 2020 menunjukkan perekonomian rumah tangga mengalami 
keterpurukan sehingga pemerintah mengambil kebijakan, misalnya pemberian bantuan sosial yang selanjutnya memberikan hasil bahwa dalam beberapa bulan ke depan masyarakat optimis untuk bekerja tapi masih tetap membatasi konsumsi rumah tangga karena kondisi ketidakpastian ekonomi yang masih terjadi sampai saat ini (http://lipi.go.id/siaranpress/survei-dampak-

pandemi-covid-19-terhadap-ekonomi-rumahtangga-indonesia/22123).

Hadiwardoyo (2020) melaporkan bahwa pandemi Covid-19 mengakibatkan kerugian nasional yang sangat besar dengan dua cara perhitungannya yaitu dengan asumsi perputaran uang di Jabodetabek sebesar $70 \%$ dari total uang beredar di Indonesia, dan asumsi perbandingan Proporsi Pendapatan Domestik Regional Bruto (PDRB) dari kawasan yang memberlakukan pembatasan sosial. Perhitungan kerugian menggunakan asumsi pertama didapatkan adanya kerugian sekitar $923 \mathrm{~T}$ rupiah apabila terjadi penghentian sosial selama 1 bulan dan perpanjangan PSBB selama 2 minggu akan mengakibatkan kerugian sekitar $1260 \mathrm{~T}$ rupiah atau setengah dari APBN 2020. Selanjutnya dengan asumsi kedua, maka diperkirakan kerugian negara hampir $300 \mathrm{~T}$ rupiah dan apabila PSBB diperpanjang 2 minggu maka kerugian akan meningkat sekitar $140 \mathrm{~T}$ rupiah.

Untuk membantu program pemerintah dalam memulihkan sektor ekonomi rumah tangga, melalui perguruan tinggi, Universitas Veteran Bangun Nusantara (Univet Bantara) Sukoharjo mencoba merintis kegiatan kewirausahaan di RT 001/008 Kelurahan Bulakrejo Kecamatan Sukoharjo Kabupaten Sukoharjo. sebagai penggerak perekonomian baru. RT 001/008 Kelurahan Bulakrejo Kecamatan Sukoharjo Kabupaten Sukoharjo terdapat sekitar 50 kepala keluarga (KK), dan sebelum terjadi pandemi, 70\% bermata pencaharian sebagai pekerja pabrik, $10 \%$ bermata pencaharian sebagai pedagang, dan sisanya bekerja sebagai PNS. Pandemi ini telah banyak merumahkan atau PHK pekerja pabrik sehingga pada RT ini banyak yang berada di rumah dan bertahan hidup dengan berwirausaha, misalnya bercocok tanam dan beternak ikan lele. Hasil dari bercocok tanam dan beternak ikan pada awalnya dapat sedikit membantu perekonomian warga RT tersebut akan tetapi beberapa waktu ini musim yang tidak menentu dan curah hujan yang besar sedikit banyak mempengaruhi ternak ikan dan perkembangan tanaman warga RT tersebut. Hal ini dapat diketahui saat wawancara awal dengan warga RT tersebut bahwa cuaca dengan curah hujan yang relatif tinggi pada akhir-akhir ini mengakibatkan ikan lele lama berkembang sehingga kebutuhan pakan juga meningkat. Hal yang mirip juga dilaporkan warga RT tersebut bahwa tanaman yang ditanam juga mengalami penurunan hasil dikarenakan curah hujan yang relatif tinggi akhirakhir ini. Hal-hal tersebut menjadikan tim Pengabdian kepada Masyarakat Prodi Pendidikan Biologi Univet Bantara untuk menawarkan solusi terhadap permasalahan yang dihadapi masyarakat RT tersebut menggunakan ekoenzim.

Ekoenzim pertama kali diperkenalkan oleh ilmuwan asal Thailand sekaligus beliau mendapatkan penghargaan dari PBB tahun 2013 karena dampak manfaat yang sangat tinggi bagi lingkungan. Ekoenzim ini merupakan hasil kokultivasi antara sampah organik rumah tangga dengan air gula (misal: gula jawa, molase, dll) sehingga hasil fermentasinya diharapkan akan menghasilkan gas O3 (ozon) dan juga suatu cairan yang dapat digunakan sebagai pembersih peralatan rumah tangga dan pupuk hayati untuk meningkatkan pertumbuhan dan perkembangan tanaman. Keunggulan yang ditawarkan dari penggunaan ekoenzim ini memang sangat banyak tapi juga mempunyai kelemahan yaitu proses fermentasi yang cukup lama yaitu sekitar 1-3 bulan sehingga dibutuhkan kesabaran dalam membuat ekoenzim yang ramah lingkungan ini (http://www.tzuchi.or.id/ruang-hijau/ekoenzimlarutan-ajaib-dari-sampah-organik/13). Selain itu, ekoenzim juga dilaporkan dapat diaplikasikan pada ternak ikan lele dengan dosis sekitar $0.1-1 \mathrm{mg} / \mathrm{L}$ walaupun pengaruh positifnya kurang signifikan terhadap pertumbuhan dan perkembangan ikan lele (Kusumawati et al., 2018).

Beberapa hal yang telah disebutkan di atas selanjutnya mendasari tim kami dalam memperkenalkan salah satu alternatif solusi dari permasalahan mitra yaitu masyarakat RT. 001/008 Kelurahan Bulakrejo Kecamatan Sukoharjo Kabupaten Sukoharjo dalam hal bercocok tanam maupun ternak ikan pada masa pandemi dan cuaca akhir-akhir ini yang tidak bersahabat. Kegiatan ini diharapkan dapat menjadi penggerak ekonomi rumah tangga sehingga kemampuan finansial masyarakat mitra dapat meningkat. Dari hasil 
pertemuan tim dengan masyarakat disepakati bahwa masyarakat menerima program pengabdian masyarakat dari tim dosen Program Studi Pendidikan Biologi Univet Bantara Sukoharjo dengan membuat ekoenzim dengan bahan baku berupa sampah dapur organik. Tim kami mengikutsertakan beberapa masyarakat yang tinggal di RT tersebut untuk terlibat dalam kegiatan ini.

\section{Metode}

Berdasarkan permasalahan yang dihadapi masyarakat RT. 001/008 Kelurahan Bulakrejo Kecamatan Sukoharjo Kabupaten Sukoharjo, solusi yang ditawarkan tentunya diperlukan sebagai bentuk kegiatan yang memberikan pengalaman dan pemahaman, dengan tujuan masyarakat mempunyai pengetahuan dan ketrampilan dalam pembuatan ekoenzim. Bentuk kegiatan pengabdian ini dilakukan dengan cara penyuluhan dan pelatihan antara lain:

1. Ceramah (penyampaian materi), berkaitan dengan seluk-belu ekoenzim sampai dengan berbagai manfaatnya.

2. Diskusi dan tanya jawab. Diskusi dilakukan guna memecahkan permasalahan yang dihadapi masyarakat RT. 001/008 Kelurahan Bulakrejo Kecamatan Sukoharjo Kabupaten Sukoharjo pada saat pandemi seperti sekarang ini, salah satunya melalui pelatihan pembuatan ekoenzim.

3. Praktik membuat ekoenzim.

4. Pembimbingan dilakukan dalam pengarahan bagi mitra ketika berpraktik.

\section{Hasil dan Pembahasan}

Kegiatan Pengabdian kepada Masyarakat (Pengabmas) ini diawali dengan identifikasi masalah yang dihadapi oleh mitra yaitu masyarakat RT 001/008 Kelurahan Bulakrejo Kecamatan Sukoharjo Kabupaten Sukoharjo, yang dilaksanakan pada tanggal 9 Maret 2021, di rumah salah satu warga yaitu ketua Kelompk Wanita Tani (KWT) Cendana; Ibu Narti. Dari diskusi yang dilaksanakan secara protokol kesehatan (prokes) yang ketat, diketahui bahwa pandemi Covid-19 yang terjadi sampai saat ini telah berdampak negatif bagi masyarakat tersebut, salah satunya di sektor perekonomian yaitu banyak warga yang dirumahkan akibat pandemi ini.
Selanjutnya tim Pengabmas Pendidikan Biologi Univet Bantara Sukoharjo menawarkan salah satu solusi terkait hal tersebut, yaitu pelatihan pembuatan Ekoenzim. Solusi ini sebenarnya mempunyai hubungan yang erat dengan masalah yang dihadapi masyarakat tersebut, yaitu salah satu manfaat dari Ekoenzim adalah dapat digunakan untuk pupuk tanaman serta agen yang berperan dalam peningkatan kualitas air kolam ikan. Dengan manfaat ini, diharapkan dapat membantu perekonomian mayarakat mitra yang juga mempunyai kebiasaan bahkan mata pencaharian dadakan yaitu bertanam sayur dan ternak lele.

Kegiatan Pengabmas selanjutnya adalah sosialisasi yang berisi tentang pengenalan Ekoenzim, manfaat, dan cara pembuatannya. Kegiatan ini dilakukan pada tanggal 15 Juni 2021, di rumah ketua RT 001/008 Kelurahan Bulakrejo Kecamatan Sukoharjo Kabupaten Sukoharjo. Kegiatan Pengabmas ini dilakukan dengan metode ceramah dan membawa contoh Ekoenzim yang telah dibuat tim Pengabmas (Gambar 1). Sebelum ceramah terkait pengertian, manfaat, dan pembuatan Ekoenzim, dilakukan pre-test, yang didapatkan hasil bahwa seluruh warga RT 001/008 Kelurahan Bulakrejo Kecamatan Sukoharjo Kabupaten Sukoharjo yang datang pada pertemuan ini ternyata belum mengetahui tentang Ekoenzim. Kegiatan ceramah kegiatan Pengabmas ini dilakukan sekitar 30 menit, dengan prokes yang ketat. Hasil Pengabmas pertemuan ini menunjukkan bahwa masyarakat RT 001/008 Kelurahan Bulakrejo Kecamatan Sukoharjo Kabupaten Sukoharjo terlihat antusias mengenai materi yang disampaikan, yang ditandai dengan banyaknya penanya terkait pembuatan ekoenzim.

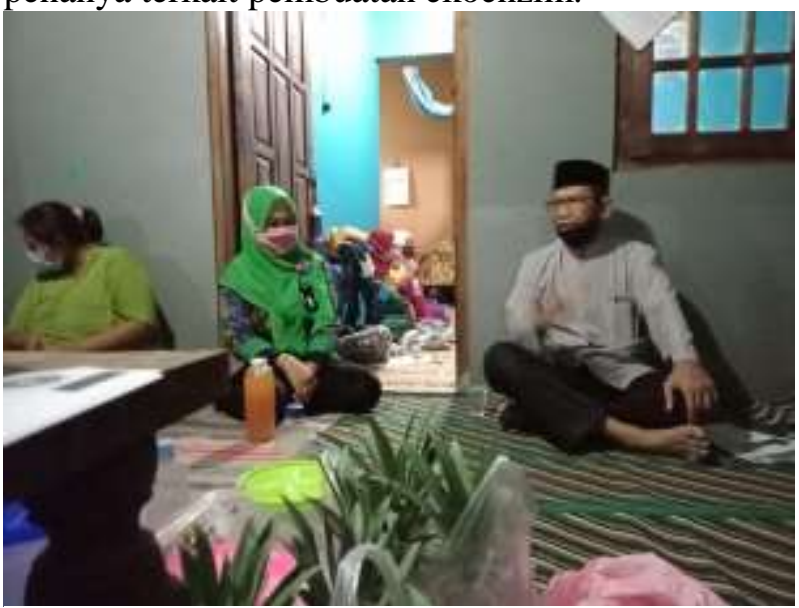

Gambar 1 Kegiatan Pengabmas tahap II tentang pembuatan ekoenzim 
Kegiatan Pengabmas selanjutnya dilakukan pada tanggal 26 Juni 2021 di rumah ketua KWT Cendana, yang dihadiri oleh perwakilan ibu-ibu pengurus PKK RT tersebut sebanyak 5 orang. Sedikitnya peserta yang hadir lebih didasarkan dengan situasi pandemi yang tidak memungkinkan untuk mendatangkan warga mitra dalam jumlah banyak. Walaupun peserta hanya 5 orang, tetapi mereka sangat antusias dalam mengikuti Pelatihan Pembuatan Ekoenzim. Awal kegiatan ditandai dengan cara membuat media cair untuk fermentasi, yaitu molase dan air. Perbandingan molase dan air yang digunakan adalah 1:10. Wadah yang digunakan disesuaikan dengan banyaknya media cair serta sisa sayur dan buah yang akan dibuat menjadi ekoenzim. Setelah wadah diisi dengan media cair yang telah memenuhi perbandingan komposisi standar, maka hal yang dilakukan selanjutnya adalah menyiapkan sisa sayur dan buah. Sisa sayur dan buah yang digunakan dalam kegiatan Pengabmas kali ini ada beberapa jenis, yaitu kulit kacang hijau, kulit wortel, jambu air, kulit nanas, kulit jeruk, dan daun seledri. Berat sisa sayur dan buah yang digunakan harus disesuaikan dengan perbandingan standar yaitu 3 bagian dari komposisi air dan molase, sehingga didapatkan perbandingan komposisi secara keseluruhan yaitu molase : sisa sayur buah : air $=1: 3: 10$. Sebelum dilakukan penimbangan terhadap sisa sayur dan buah, dilakukan terlebih dahulu pencucian terhadap sisa sayur dan buah yang akan digunakan, dengan tujuan untuk mengurangi kotoran yang menempel pada sisa sayur dan buah tersebut. Sisa sayur dan buah yang telah ditimbang sesuai perbandingan komposis standar, selanjutnya dimasukkan ke dalam wadah yang berisi media cair fermentasi yang telah disiapkan sebelumnya. Pengadukan, penutupan, serta pelabelan dilakukan setelah langkah tersebut.

Karena situasi pandemi yang semakin memprihatinkan, maka tim Pengabmas, memutuskan untuk memberikan pelatihan dalam pemanenan Ekoenzim pada hari yang sama saat pelatihan pembuatan ekoenzim. Pemanenan ekoenzim siap panen yang telah dipersiapkan sebelumya oleh tim Pengabmas, menggunakan kain bersih dan larutan ekoenzim ditampung di wadah yang bersih. Penyaringan dengan kain bersih dilakukan 2x dengan tujuan mendapatkan larutan ekoenzim yang jernih terbebas dari ampas. Ampas yang didapatkan selanjutnya dapat digunakan untuk pupuk tanaman, sedangkan larutan ekoenzim dapat digunakan untuk sabun cuci, penambah kualitas air kolam, serta penyubur tanaman. Selama kegiatan Pengabmas ini berlangsung, tampak antusiasme dari para peserta, bahkan merekan telah terampil membuat media cair sampai pemanenan ekoenzim (Gambar 2). Hal ini dapat dibuktikan dengan posttest yang diberikan yaitu semua peserta pelatihan mampu membuat dan memanen ekoenzim.

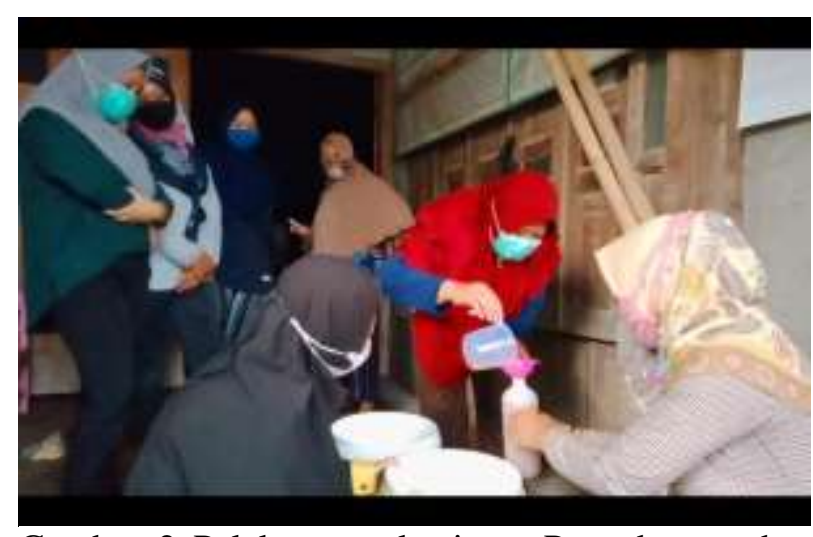

Gambar 2 Pelaksanaan kegiatan Pengabmas tahap III tentang pembuatan ekoenzim

Evaluasi kegiatan Pengabmas yang dilakukan sebanyak 3x, secara umum dapat dilihat hasilnya seperti yang tertera pada Tabel 1 .

Tabel 1 Evaluasi Kegiatan Pengabmas

\begin{tabular}{|c|c|c|c|}
\hline No & Kegiatan & Capaian & Indikator \\
\hline 1 & $\begin{array}{l}\text { Analisis } \\
\text { situasi awal }\end{array}$ & Berhasil & $\begin{array}{l}\text { Diketahui } \\
\text { masalah yang } \\
\text { dihadapi } \\
\text { masyarakat } \\
\text { mitra. }\end{array}$ \\
\hline 2 & $\begin{array}{l}\text { Sosialisasi } \\
\text { terkait } \\
\text { pengenalan, } \\
\text { pembuatan, } \\
\text { dan manfaat } \\
\text { ekoenzim }\end{array}$ & Berhasil & $\begin{array}{l}\text { Masyarakat } \\
\text { mitra menjadi } \\
\text { mengenal } \\
\text { tentang } \\
\text { ekoenzim }\end{array}$ \\
\hline 3 & $\begin{array}{l}\text { Pelatihan } \\
\text { pembuatan } \\
\text { dan } \\
\text { pemanenan } \\
\text { ekoenzim }\end{array}$ & Berhasil & $\begin{array}{l}\text { Peserta } \\
\text { pelatihan } \\
\text { mengetahui cara } \\
\text { pembuatan dan } \\
\text { pemanenan } \\
\text { ekoenzim }\end{array}$ \\
\hline
\end{tabular}

\section{Kesimpulan}

Setelah melakukan kegiatan Pengabmas sebanyak 3x, tim pengabmas dapat menarik 
kesimpulan sebagai berikut: ekoenzim dapat digunakan sebagai salah satu solusi masalah yang dihadapi masyarakat mitra terkait pandemic Covid19, masyarakat mitra dapat memahami apa itu ekoenzim, cara pembuatan, serta manfaatnya, dan masyarakat mitra yang diwakili oleh ibu-ibu PKK dapat mempraktikkan dengan benar tentang cara pembuatan dan pemanenan ekoenzim.

\section{Saran}

Kegiatan penyuluhan terkait produksi massal dan pemasaran produk ekoenzim perlu dilakukan mengingat dapat meningkatkan ekonomi serta pemanfaatan limbah sayur dan buah secara nyata.

\section{Ucapan Terima Kasih}

Segenap tim Pengabmas sekaligus penulis mengucapkan terima kasih kepada seluruh civitas Universitas Veteran Bangun Nusantara yang telah memberikan dukungan materi dan nonmateri sehingga kegiatan Pengabmas ini dapat berlangsung dan hasilnya dapat terpublikasikan.

\section{Daftar Pustaka}

Abe, A. (2001). Perencanaan daerah: memperkuat prakarsa rakyat dalam otonomi daerah. Lapera Pustaka Utama.

Eviati \& Sulaeman. (2009). Analisa Kimia Tanah, Tanaman, Air Dan Pupuk. Bogor : Badan Penelitian Dan Pengembangan Pertanian Departemen Pertanian.

Gesriantuti, N., Elsie, E., Harahap, I., Herlina, N., \& Badrun, Y. (2017). Pemanfaatan limbah organik rumah tangga dalam pembuatan pupuk bokashi di Kelurahan Tuah Karya, Kecamatan Tampan, Pekanbaru.. Jurnal Pengabdian UntukMu NegeRI, 1(1), 72-77.

Hadiwardoyo, W. (2020). Kerugian Ekonomi Nasional Akibat Pandemi Covid19. Baskara: Journal of Business and Entrepreneurship, 2(2), 83-92.

Hemalatha, M., \& Visantini, P. (2020). Potential use of eco-enzyme for the treatment of metal based effluent. In IOP Conference Series: Materials Science and Engineering (Vol. 716, No. 1, p. 012016). IOP Publishing. https://bulelengkab.go.id/assets/instansikab/82/bank data/modul-eco-enzyme-2020-12.pdf

http://lipi.go.id/siaranpress/survei-dampakpandemi-covid-19-terhadap-ekonomirumah-tangga-indonesia/22123

http://www.tzuchi.or.id/ruang-hijau/ekoenzimlarutan-ajaib-dari-sampah-organik/13

Kirna, I. M., Selamat, I. N., \& Antara, K. L. (2013). Probiofish Dan Pakan Fermentasi Untuk Mengatasi Masalah Pakan Pada Budidaya Lele. Ngayah: Majalah Aplikasi IPTEKS, 4(2).

Kusumawati, A. A., Suprapto, D., \& Haeruddin, H. (2018). Pengaruh ekoenzim terhadap kualitas air dalam pembesaran ikan lele (Clarias gariepinus). Management of Aquatic Resources Journal (MAQUARES), 7(4), 307-314.

Megah, S. I., Dewi, D. S., \& Wilany, E. (2018). Pemanfaatan limbah rumah tangga digunakan untuk obat dan kebersihan. Minda Baharu, 2(1), 50-58.

Nasih, W. (2010). Pengelolaan Sampah yang Ramah Lingkungan di Sekolah, Pelatihan Pengembangan Sekolah Hijau untuk guruguru SMK RSBI se-DIY. LPPM UGM bekerja sama dengan Dinas Pendidikan, Pemuda dan Olah Raga Provinsi DIY.

Rubin, M. B. (2001). The history of ozone. The Schönbein period, 1839-1868. Bull. Hist. Chem, 26(1), 40-56.

Sulistyawati, E., Mashita, N., \& Choesin, D. (2007). Pengaruh agen dekomposer terhadap kualitas hasil pengomposan sampah organik rumah tangga. Jurnal Penelitian Sains \& Teknologi, Bandung, Institut Teknologi Bandung.

Utpalasari, R. L., \& Dahliana, I. (2020). Analisis hasil konversi ecoenzyme menggunakan nenas (Ananas comosus) dan pepaya (Carica papaya L.). Jurnal Redoks, 5(2), 130-135. 